\title{
Jenis-Jenis Jamur Rizosfer dan Jamur Busuk Batang Karet dari Perkebunan Karet (Hevea Brasiliensis Muell Arg.) di Desa Tajok Kayong
}

\author{
${ }^{1}{ }^{1}$ Rahmawati ${ }^{1}$ \\ Sisilia Hainawati ,Rahmawati , Mukarlina \\ Program Studi Biologi, FakultasMIPA, UniversitasTanjungpura, Jalan Prof. Dr. H. Hadari Nawawi, Pontianak, \\ Email korespondensi: sisiliahaina@gmail.com
}

\begin{abstract}
Rhizosphere is a fungus that plays an important role in the process of plant growth and development. This study aims to determine the morphological characters of rhizosphere fungi in rubber plants and rubber stem rot fungi. Sampling of rhizosphere fungi is carried out in rubber plantations. Tajok Kayong Village, Nanga Tayap District, Ketapang Regency. Isolation, identification was carried out at the Microbiology Laboratory, Faculty of Mathematics and Natural Sciences, Tanjungpura University, from February to June 2018. method of isolation of rhizosphere fungi using dilution method and method of isolation of rubber stem rot fungi by dilution method and direct planting method. The isolation results showed 7 rhizosphere fungi isolates, namely members of Aspergillus sp. (JTS 5, 6, 7, 8), Mucor sp. (JTS 10), and members of the Penicillium sp. Species. (JTS 2, and JTS 9), and rubber stem rot fungi, namely members of the species Corticium sp.
\end{abstract}

Keywords: Rubber, Mucor, Corticium, Aspergillus, Penicillium.

\section{PENDAHULUAN}

Tanaman karet (Hevea brasiliensis Muell Arg.) merupakan tanaman perkebunan penghasil getah yang menjadi salah satu komoditi unggulan di Indonesia. Menurut data Statistik dari Direktorat Jenderal Perkebunan (2017), pada Tahun 20152017 Indonesia memiliki luas area perkebunan tanaman karet sebesar 3.621.102 Ha dengan produktivitas hasil perkebunan karet sebesar 1.507 $\mathrm{Kg} / \mathrm{Ha}$. Kalimantan Barat memiliki total luas area perkebunan tanaman karet sebesar $365.296 \mathrm{Ha}$ dengan produktivitas hasil perkebunan tanaman karet sebesar $749 \mathrm{~kg} / \mathrm{Ha}$. Hal ini menunjukkan bahwa produktivitas hasil perkebunan tanaman karet di Indonesia masih rendah khususnya di Kalimantan Barat.

Jamur yang menguntungkan sangat melimpah jumlahnya, baik yang berada di sekitar perakaran (rizosfer) maupun di jaringan tanaman (endofit). Tistama dan Nugroho (2007) mengemukakan bahwa pada lapisan rizosfer di sekitar tanaman karet yang sehat mengandung jamur yang berpotensi sebagai biofungisida dan biofertilizer yang dapat meningkatkan produktivitas tanaman karet.

Hasil penelitian Amaria et al. (2013) perkebunan karet di Lampung, Sumatera Selatan, Jawa Tengah, dan Jawa Barat, diperoleh 134 jenis jamur rhizosfer. Berdasarkan hasil penelitian Putri et al. (2015), ditemukan jamur rizosfer tanaman karet di perkebunan karet Kecamatan Batang Tarang, Kabupaten Sanggau, Kalimantan Barat, yaitu anggota spesies Trichoderma sp. W1, Penicillium sp.1 W2, Penicillium sp.2 W3 dan Chaetomium sp.W4.

Perkebunan tanaman karet lain yang ada di Kalimantan Barat terdapat di Desa Tajok Kayong, Ketapang, yang saat ini batang tanaman karet mengalami penyakit bergejala busuk. Penyakit tersebut disebabkan oleh jamur dengan gejala kulit batang busuk kemudian mengering, semakin lama dan akhirnya mati serta tidak menghasilkan lateks. Informasi atau penelitian tentang jenis-jenis jamur rizosfer dan jamur busuk batang tanaman karet di Desa Tajok Kayong masih sedikit. Oleh karena itu, perlu dilakukan penelitian untuk mengetahui jenisjenis jamur rizosfer dan jamur busuk batang sebagai langkah awal mengetahui dalam pengendalian jamur busuk batang tanaman karet.

\section{BAHAN DAN METODE}

\section{Waktu dan Tempat Penelitian}

Penelitian ini dilaksanakan pada bulan Februari hingga Juni 2018. Pengambilan sampel tanah dan pengambilan batang tanaman karet yang mengalami busuk batang dilakukan di salah satu perkebunan karet, Desa Tajok Kayong, Kecamatan Nanga Tayap, Kabupaten Ketapang. Tahap isolasi, dan identifikasi di lakukan di Laboratorium 
Mikrobiologi, Jurusan Biologi, Fakultas Matematika dan Ilmu Pengetahuan Alam, Universitas Tanjungpura, Pontianak.

\section{Bahan}

Bahan-bahan yang digunakan adalah Agar, akuades, alkohol 70\%, antibiotik, asam Laktat, batang tanaman karet yang terkena penyakit busuk pangkal batang, gula, Kalium Hidroksida $(\mathrm{KOH})$, kentang, tanah rizosfer tanaman karet sehat.

\section{Sterilisasi Alat}

Alat-alat seperti cawan petri, erlenmeyer, gelas ukur, gelas piala jarum ose, pinset, pisau skalpel, dan tabung reaksi dicuci dengan larutan detergen dan dikeringkan. Alat tersebut selanjutnya disterilisasi mengunakan autoklaf dengan suhu $121^{\circ} \mathrm{C}$ dan tekanan $1 \mathrm{~atm}$ selama 15 menit.

\section{Pembuatan Media}

Media PDA (Potato Dextrose Agar) dibuat dengan rebusan 1 liter akuades dengan cara merebus 200 gram kentang yang sudah kemudian disaring ekstraknya, kemudian ditambahkan gula 20 gram, dan 15 gram agar, setelah mendidih ditambahkan antibiotik khloramphenicol. Larutan kemudian dimasukkan ke dalam erlenmeyer yang telah dipersiapkan, masing-masing sebanyak $250 \mathrm{ml}$, kemudian disterilisasi menggunakan autoklaf. Sesudah disterilisasi media PDA siap untuk dituang kedalam cawan petri yang telah disiapkan, kemudian dibiarkan media tersebut dingin (Achmad et al., 2013).

Pengambilan sampel jamur busuk batang di Perkebunan Karet Desa Tajok Kayong

Sampel yang diambil pada tanaman karet yang bergejala sakit busuk batang. Pengambilan sampel dilakukan dengan memotong bagian batang tanaman karet yang mengalami busuk batang karet, selanjutnya sampel dibawa ke Laboratorium Mikrobiologi, Fakultas Matematika dan Ilmu Pengetahuan Alam, Unversitas Tanjungpura, untuk dilakukan isolasi, identifikasi dan karakterisasi.

\section{Isolasi Jamur Patogen Penyebab Busuk Batang} Tanaman Karet

Isolasi jamur patogen dilakukan dengan metode tanam langsung pada media PDA. Isolat patogen diisolasi dengan cara memotong bagian batang karet dari lapisan luar ke lapisan yang terserang penyakit busuk batang $1 \mathrm{~cm}$, kemudian dicuci dengan klorox, dan setelah itu direndam dalam alkohol $70 \%$, kemudian dibilas menggunakan akuades steril.
Potongan batang, masing-masing diletakkan pada media PDA padat, selanjutnya diinkubasi selama 7 hari pada suhu $28^{\circ} \mathrm{C}$ (Purwantisari et al., 2009). Setelah jamur tumbuh, koloni jamur yang tumbuh diambil dengan ose, kemudian diinokulasikan pada media PDA yang baru untuk memperoleh biakan murni (Rohayatun et al., 2017).

\section{Pengambilan Sampel Jamur Rizosfer Tanaman Karet}

Sampel yang diambil di sekitar perakaran tanaman karet yang sehat. Pengambilan sampel dilakukan dengan metode purposive sampling yang dilakukan pada 3 titik (pohon) tanaman karet dengan 3 pengulangan pada setiap titik. Sampel tanah diambil dengan jarak 10-15 cm dan kedalaman 0-20 cm, masing-masing sebanyak kurang lebih $10 \mathrm{~g}$. Semua sampel tanah dikompositkan, lalu diambil sebanyak 100 gram untuk isolasi jamur rizosfer. Sampel tanah diambil dan dimasukan ke dalam kantong plastik kemudian sampel disimpan dalam ice box, selanjutnya sampel dibawa ke laboratorium untuk dilakukan isolasi, identifikasi dan karakterisasi.

\section{Isolasi jamur rizosfer dari tanaman karet perkebunan karet}

Isolasi jamur rizosfer tanaman karet dilakukan dengan menggunakan metode pengenceran dan metode tuang (pour plate). Sampel tanah ditimbang sebanyak $1 \mathrm{~g}$ dan dimasukan ke dalam tabung reaksi yang telah berisi akuades steril sebanyak $9 \mathrm{ml}$ dan dihomogenkan. Sampel tanah yang telah dihomogenkan kemudian diencerkan hingga tingkat pengenceran $10^{-5}$. Pengenceran ini dilakukan dengan cara mengambil $1 \mathrm{ml}$ suspensi dari tabung $10^{-1}$, kemudian dimasukan kedalam tabung $10^{-2}$, kemudian tabung $10^{-2}$ ke tabung $10^{-3}, 10^{-4}, 10^{-5}$ dilakukan seperti yang dilakukan pada tabung $10^{-1}$. Setelah itu dari tiap-tiap pengenceran $10^{-1}, 10^{-2}, 10^{-3}$, $10^{-4}$ dan $10^{-5}$ dipipet sebanyak $1 \mathrm{ml}$, kemudian dituang ke dalam media PDA dengan metode pour plate. Media yang telah padat diinkubasikan pada suhu $28{ }^{\circ} \mathrm{C}$ selama 3-7 hari (Purwantisari \& Rini, 2009). Setelah jamur tumbuh, koloni masingmasing jamur diambil dengan ose, kemudian ditumbuhkan pada media PDA baru untuk diperoleh biakan murni (Samson et al., 2010).

\section{Identifikasi Jamur Rizosfer}

Gelas objek disterilisasi terlebih dahulu menggunakan alkohol $70 \%$. Kemudian diambil koloni jamur dengan menggunakan jarum ose dan diletakkan di atas gelas objek lalu ditetesi dengan larutan $\mathrm{KOH}$, kemudian ditutup dengan cover glass. 

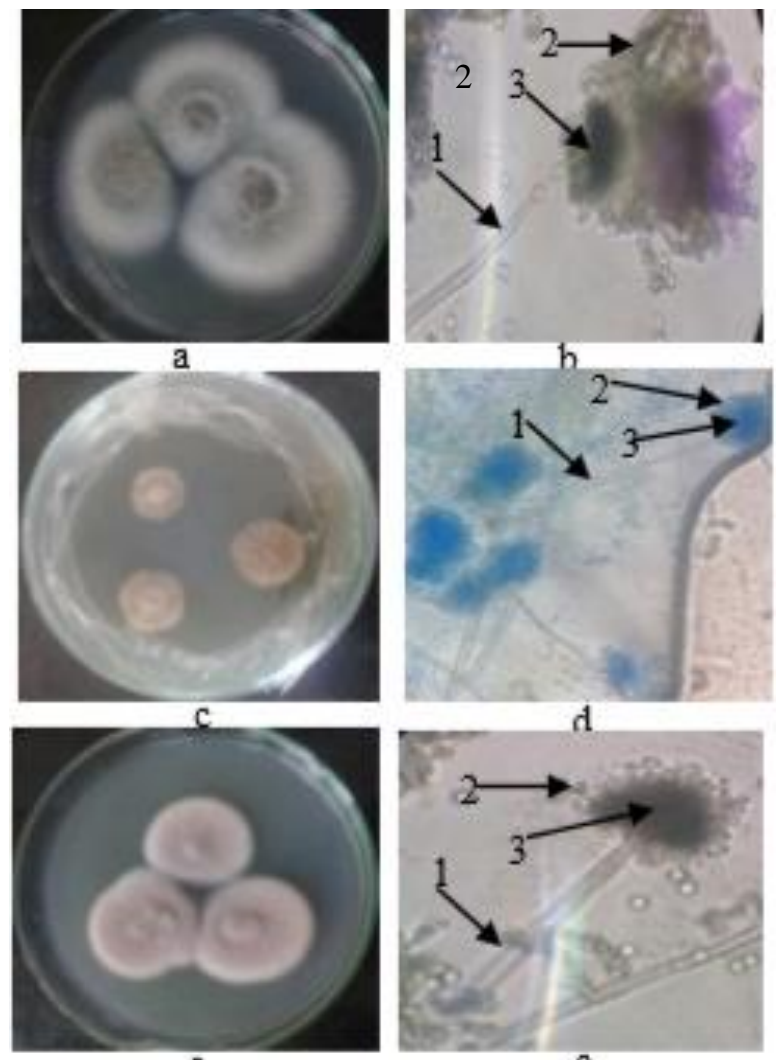

e
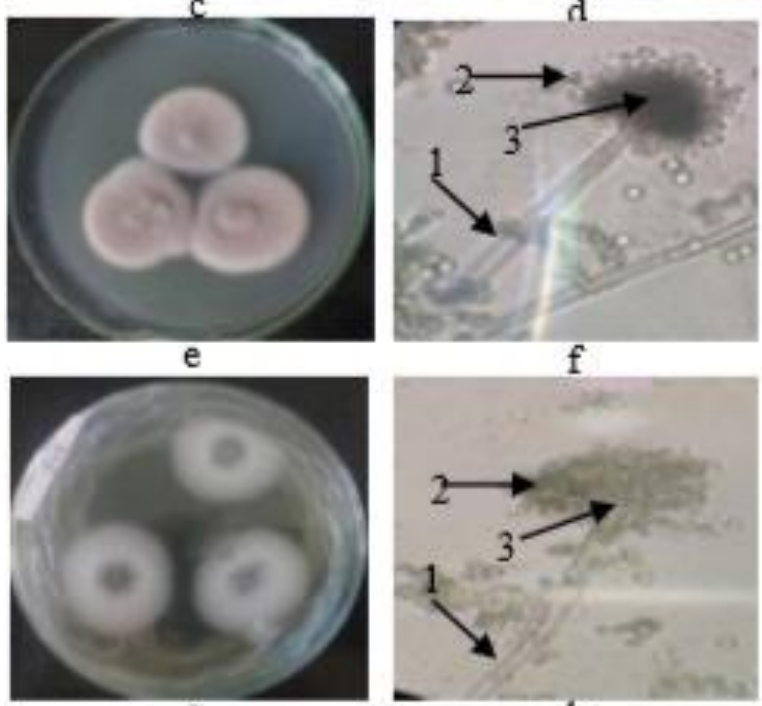

g

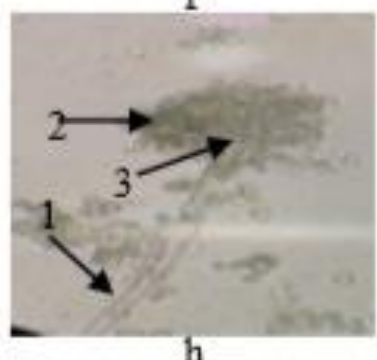

h

Gambar 1 Koloni Jamur Rizosfer Karet, pada hari ke-7 di media PDA.

Keterangan:(a,b) Koloni dan Mikromorfologis jamur Aspergillus sp. (JTS 5)

(c,d) Koloni dan Mikromorfologis jamur Aspergillus sp. (JTS 6)

$(\mathrm{e}, \mathrm{f})$ Koloni dan Mikromorfologis jamur Aspergillus sp. (JTS 7)

$(\mathrm{g}, \mathrm{h})$ Koloni dan Mikromorfologis jamur Aspergillus sp. (JTS 8)

(1) Konidiofor, (2) Konidia, (3) Vesikula

Preparat diamati dengan menggunakan mikroskop cahaya. Jamur yang tumbuh diidentifikasi berdasarkan karakter morfologis koloni secara makroskopis seperti diameter koloni, warna koloni, bentuk dan tekstur permukaan koloni, serta secara mikroskopis meliputi struktur hifa, dan struktur reproduksi. Identifikasi jamur hasil isolasi mengacu pada buku identifikasi jamur, Descriptions of Medical Fungi, (Sarah et al., 2016) dan Food and Indoor Fungi (Samson et al., 2010), Taxonomic

studies on the genus Aspergillus (Samson et al., 2011).

\section{Analisis Data}

Data-data yang diperoleh dari hasil isolasi dan identifikasi disajikan dalam bentuk foto dan deskripsi berdasarkan karakter morfologis jamur rizosfer yang telah diperoleh dari perkebunan karet.
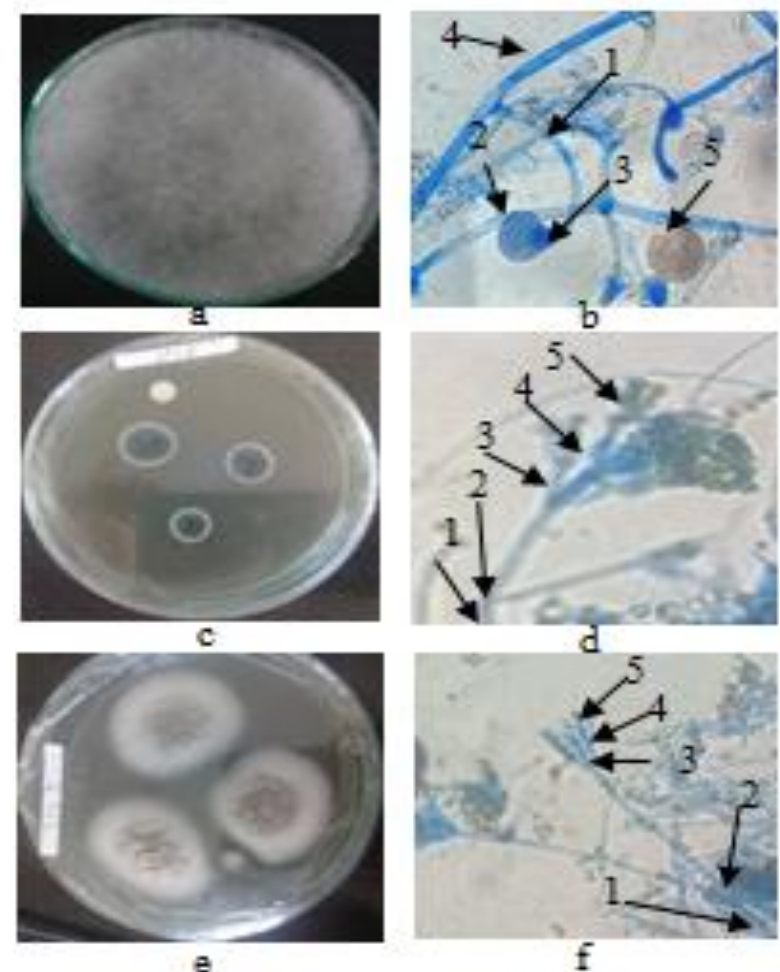

Gambar 2. Koloni Jamur Rizosfer Karet, pada hari ke-7 di media PDA.

Keterangan:(a,b) Koloni dan Mikromorfologis jamur Mucor sp. (1) Sporangiofor, (2) Sporangium (3) Kollumela, (4) Stolon, (5) Sporangiospora

(c,d) Koloni dan Mikromorfologis jamur Penicillium sp. (JTS 2)

(e,f) Koloni dan Mikromorfologis jamur Penicillium sp. (JTS 9)

(1) Konidiofor, (2)Percabangan, (3) Metula, (4) Fialid, (5) Konidia

Karakteristik Jamur Rizosfer dari Perkebunan Karet Desa Tajok Kayong

Berdasarkan isolasi dan identifikasi jamur rizosfer dari tanaman karet (Hevea brasiliensis Muell Arg.) ditemukan 7 jenis jamur yaitu anggota spesies Aspergillus spp. (JTS 5), (JTS 6), (JTS 7) dan (JTS 8), Mucor sp. (JTS 10), dan anggota spesies Penicillium spp. (JTS 2) dan (JTS 9) (Gambar 1 dan 2). Berdasarkan pengamatan secara makroskopis, 
karakteristik jamur anggota spesies Aspergillus sp. (JTS 5), (JTS 6), (JTS 7), (JTS 8), sesuai dengan karakteristik jamur anggota genus Aspergillus menurut pernyataan Samson et al. (1995) dan Sarah et al. (2016) bahwa jamur anggota spesies Aspergillus sp. memiliki ciri-ciri koloni warna hijau, kuning kecoklatan, ungu muda, dan putih kehijauan sebagian besar terdiri dari konidiofor yang tegak, pada bagian atas konidiofor akan membulat membentuk vesikula, dalam vesikula terdapat lapisan palisade yang tersusun oleh fialid yang disebut dengan vesikula uniseriate dan vesikula biseriat apabila terdapat lapisan sel subtending metula dan fialid. Vesikel, fialid, metula (jika ada) dan konidia membentuk kepala konidia.

Karakteristik Morfologis Jamur Busuk Batang Karet $(J B K)$

Gejala secara makroskopis jamur pada batang tanaman karet yang busuk yaitu adanya lapisan jamur berwarna putih hingga merah muda dan masuk ke bagian kayu, keluar getah/lateks berwarna hitam dibagian tanaman yang terserang, yang menyebabkan permukaan batang tanaman menjadi busuk, batang tanaman mati dan mudah patah oleh angin (Gambar 3a).

Hasil pengamatan gejala secara makroskopis atau secara langsung batang karet yang terserang jamur menunjukan batang tersebut berwarna putih sampai berwarna merah muda apabila pada awal stadium penyakit ini, getah yang menempel pada bagian batang yang terserang kemudian berwarna hitam, batang yang terserang perlahan-lahan rusak sehingga mudah patah di bagian tengah batang yang terserang. Koloni awal jamur anggota spesies Corticium sp. tampak pada batang atau cabang yang kulitnya sudah berwarna cokelat, tetapi belum membentuk lapisan gabus yang tebal. Isolat jamur yang diisolasi dari gejala busuk batang tanaman karet memiliki ciri-ciri koloni bulat berdiameter $64.44 \mathrm{~mm}$, berwarna putih (Gambar 3b).

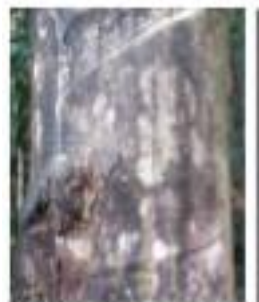

a

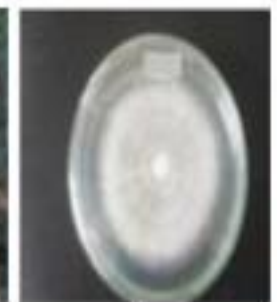

b

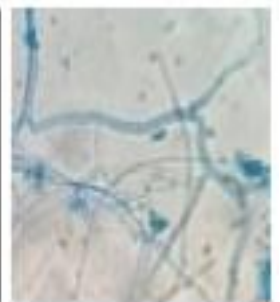

c
Keterangan : (a) Gejala awal yang tampak pada batang tanaman karet, (b),Koloni Jamur Corticium sp. (c) Hifa Jamur Corticium sp.

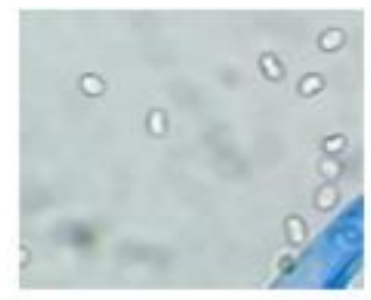

a

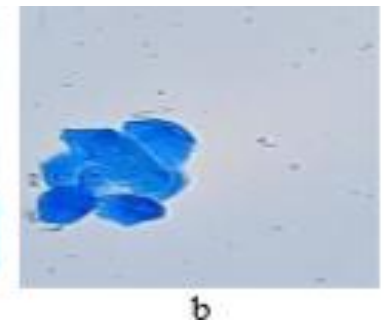

b
Keterangan : (a) Hasil pengamatan Basidiospora jamur Corticium sp. dengan menggunakan mikroskop perbesaran 40x10; (b) Konidiospora jamur Corticium sp. pada perbesaran 40x10;

\section{Pembahasan \\ Karakteristik Morfologis Jamur rizosfer dan Jamur Busuk Batang}

Berdasarkan hasil isolasi dan identifikasi jamur yang berhasil diisolasi dari rizosfer tanaman karet (Hevea brasiliensis Muell Arg.) di perkebunan karet Desa Tajok Kayong, Kecamatan Nanga Tayap, Kabupaten Ketapang. Menurut Abadi (2003) dan Ahmad et al. (2008) jamur yang paling umum ditemukan di rizosfer adalah anggota genus Penicillium dan Aspergillus. Kedua jamur ini paling banyak ditemukan di tanah karena bersifat kosmopolitan, dapat hidup hampir pada semua tipe habitat, hal ini dikarenakan jumlah spora yang banyak, selain itu jamur anggota genus Aspergillus dan Penicillium merupakan jamur saprofitik umum. Jamur hasil isolasi dari perakaran tanaman karet yang diperoleh dipengaruhi oleh faktor lingkungan di daerah perakaran tanaman karet, karena sifat jamur yang saprofit bergantung pada lingkungan dan bahan organik substrat. Faktor lingkungan yang mempengaruhi diantaranya keasaman tanah $(\mathrm{pH})$, suhu tanah dan kelembaban tanah.

Karakter yang membedakan jamur Aspergillus sp. JTS 5, 6, 7 dan 8 yaitu pada Aspergillus sp. (JTS 5) memiliki warna koloni putih kehijauan, kepala konidia berbentuk kolumar, bentuk vesikula biseriat dengan diameter koloni $40.58 \mathrm{~mm}$, Aspergillus sp. (JTS 6) memiliki warna koloni coklat, bentuk kepala konidia radiat, dan vesikula nya uniseriat, diameter koloni $18.73 \mathrm{~mm}$, Aspergillus sp. (JTS 7) memiliki warna koloni ungu muda, bentuk kepala konidia radiat dan vesikula biseriat dengan diameter koloni $30.54 \mathrm{~mm}$, Aspergillus sp. (JTS 8) memiliki warna koloni putih kehijauan, kepala konidia berbentuk radiat, vesikula uniseriat, diameter koloni $33.09 \mathrm{~mm}$. 
Jamur dengan kode isolat JTS 10 merupakan jamur anggota jenis Mucor sp., menurut Sarah et al. (2016) bahwa ciri makroskopis jamur anggota genus Mucor adalah pertumbuhan koloni sangat cepat, koloni berwarna putih sampai abu-abu kehitaman, sedangkan ciri mikroskopisnya adalah memiliki sporangiospora yang tegak dan memiliki percabangan, bentuk spora bulat, dan memiliki kolumela yang berkembang baik, sporangiospora bening sampai abu-abu kehitaman, berbeda dengan Rhizopus stolonifer yang memiliki rhizoid dan stolon sedangkan jamur anggota genus Mucor sp. tidak memiliki rhizoid seperti pada Rhizopus stolonifer, tapi jamur anggota genus Mucor sp. memiliki stolon.

Jamur dengan kode isolat JTS 2 dan JTS 9 merupakan jamur anggota jenis Penicillium sp., hal ini sesuai menurut Sarah et al. (2016) bahwa pertumbuhan koloni umumnya cepat, berwarna hijau, tapi ada juga yang berwarna putih, konidiofor tegak dan bening, percabangan, metula, fialid dan konidia. Penicillium sp. 1 memiliki warna koloni hijau keabu-abuan dengan elevasi licin, bentuk kepala konidia monoverticilate. Jamur Penicillium sp. 2 memiliki warna koloni hijau keabu-abuan dengan elevasi bergelombang dan kepala konidia berbentuk biverticilate berdasarkan Sarah, et al. (2016) ), berwarna putih kehijauan, konidiofor bening, bagian-bagiannya tersusun oleh konidiofor, percabangan, metula, fialid dan konidia.

Jamur busuk batang memiliki ciri-ciri makroskopis yaitu warna koloni putih yang seperti kapas, dengan elevasi koloni rata, tepian rata dan permukaan bawah koloni warna putih. Ciri-ciri mikroskopis jamur ini memiliki tipe percabangan yang khas, jamur ini pada pengamatan secara mikroskopis memiliki basidiospora dan konidiospora, hal ini sesuai menurut pernyataan Ambarwati, (1995) yang menyatakan bahwa jamur anggota spesies Corticium sp. memiliki 2 tipe konidia yaitu basidiospora dan konidiospora.

Umumnya jamur anggota genus Corticium mulai berkembang dari pangkal cabang atau sisi bawah cabang, bagian pangkal batang kelembapannya lebih tinggi sehingga jamur ini sangat mudah dan cepat dalam pertumbuhannya, hal ini sesuai dengan pengukuran faktor lingkungan bahwa di Perkebunan Karet di Desa Tajok Kayong memiliki nilai kelembapan $75-80 \%$. Hal ini sesuai menurut pernyataan Semangun (2000), bahwa jamur Corticium sp.(JBK) tampak pada batang atau cabang yang kulitnya sudah berwarna cokelat, tetapi belum membentuk lapisan kortisium yang tebal. Umumnya jamur mulai berkembang dari pangkal cabang atau sisi bawah cabang, karena keadaannya lebih lembab.

Menurut Hasanudin (2003), suhu dan kelembaban berpengaruh terhadap pembentukan dan lama spora jamur dapat bertahan. Suhu dan kelembaban tanah hasil pengukuran menunjukkan kisaran $28^{\circ} \mathrm{C}$ dan $75-80 \%$. Suhu dan kelembaban tanah menunjukkan kisaran yang baik bagi pertumbuhan jamur dan perkecambahan spora. Jumiyati et al. (2012) menyatakan bahwa suhu lingkungan optimum untuk pertumbuhan jamur berkisar $25-30^{\circ} \mathrm{C}$ dan suhu maksimum $25-40^{\circ} \mathrm{C}$ sedangkan kelembaban yang optimal untuk pertumbuhan jamur yaitu di bawah 80\%. Menurut Sennang et al. (2012) bahwa jamur-jamur yang diperoleh dari rizosfer dari tanaman karet keberadaanya dipengaruhi oleh metabolit sekunder yang dihasilkan oleh akar tanaman karet yaitu gula, asam amino, dan asam organic yang digunakan sebagai sumber makanan oleh jamur yang terdapat di dalam tanah.

Menurut Basu et al. (2015), jamur akan tumbuh optimal pada media dengan sumber karbohidrat dan nitrogen yang tinggi. Thongklang et al. (2010) yang menjelaskan bahwa sumber karbon (karbohidrat) adalah nutrisi yang paling penting bagi pertumbuhan jamur dan harus tersedia dalam jumlah yang lebih besar dari nutrisi yang lain. Wulandari et al. (2012) juga menjelaskan bahwa karbohidrat merupakan komponen esensial semua organisme dan zat yang paling banyak menyusun sel. Fungsi karbohidrat adalah sebagai sumber energi, membentuk struktur sel, struktur penunjang tanaman. Media PDA yang digunakan sebagai media pertumbuhan jamur anggota genus Aspergillus, Penicillium, Mucor, Corticium menunjukkan hasil lebih baik, karena PDA merupakan salah satu media kultur yang paling umum digunakan sebab formulasinya yang sederhana dan media PDA juga mengandung sumber karbohidrat yang utama yaitu kentang. Media PDA merupakan media terbaik karena kemampuannya dalam mendukung pertumbuhan pada berbagai jamur (Saha et al., 2008).

\section{DAFTAR PUSTAKA}

Abadi , A, L, 2003, Ilmu Penyakit Tumbuhan 2, Bayumedia Pulishing, Malang, Jawa Timur. 
Achmad, Nina EH , \& Eti Artiningsih Octaviani, 2013' Pengaruh pH, Penggoyangan Media, dan Penambahan Serbuk Gergaji terhadap Pertumbuhan Jamur Xylaria sp.,' Jurnal Silvikultur Tropika, vol. 04 no. 02, hal $57-61$.

Ahmad, RZ, \& Keller, NP, 2008, Isolasi Dan Identifikasi Jamur Kayu dari Hutan Pendidikan Universitas Hasanuddin di Bengo-Bengo Kecamatan Cenrana Kabupaten Maros. Jurnal Perennial, vol. 5 no. 1 hal 15-22.

Amaria, W, Taufiq, E, \& Rita H, 2013, 'Seleksi Dan Identifikasi Jamur Antagonis Sebagai Agens Hayati Jamur Akar Putih (Rigidoporus Microporus) Pada Tanaman Karet', J.TIDP, vol. 1 , no. 4 hal. $55-64$.

Ambarwati, Tjokosoedarmo, H, 1995, 'Daur Hidup Jamur Upas (Upasia salmoicolor) di Jawa', Jurnal Perlindungan Tanaman, vol.3, no. 2 hal 61-66.

Basu, S, Bose, C., Ojha, N, \& Khurana, S, 2015, Evolution of bacterial and fungal growth media. Bioinformation vol. 11 no. 4 hal: $182-184$

Direktorat Jenderal Perkebunan, 2017, Statistik Perkebunan Indonesia Tahun 2015-2017, Direktorat Jenderal Perkebunan, Kalimantan Barat.

Hasanuddin, 2003, Peningkatan peranan mikroorganisme dalam sistem pengendalian penyakit tumbuhan secara terpadu, Medan: Jurusan Hama dan Penyakit Tumbuhan, Fakultas Pertanian, Universitas Sumatera Utara,USU digital library.

Jumiyati, SH, Bintari \& I Mubarok, 2012, Isolasi dan identifikasi khamir secara morfologi di tanah kebun wisata pendidikan Universitas Negeri Semarang, Biosaintifika, vol. 4 no. 1 hal: 27-35.

Putri WK, Khotimah S., \& Linda, R, 2015' Jamur Rizosfer Sebagai Agen Antagonis Pengendali Penyakit Lapuk Fusarium Pada Batang Tanaman Karet (Hevea brasiliensis MuellArg)', Jurnal Protobiont vol 4, no.3, hal 14-18.

Rohayatun, IM, Rahmawati, \& Mukarlina, 2017,' Uji Antagonis Isolat Jamur Rizosfer Lokal Terhadap Phytophthora sp. Im5 dari Pangkal Batang Tanaman Jeruk Siam (Citrus nobilis var. microcarpa),' Protobiont vol. 6 no.3 hal $130-$ 135.
Saha, A, Mandal, P, \& Dasgupta, S, (2008), Influence of Culture Media and Environmental Factors on Mycelia Growth and Sporulation of Lasiopdiploda theobromae (Pat.) Griffon and Maubl. Journal of Enviromental Biology, vol. 29 no. 3, hal: 407- 410.

Samson, RA, Houbraken, J, Thrane, JC, Frisvad \& Andersen, F, 1995, Food and Indoor Fungi, Fungal Biodiversity Centre Utrech, Netherlands.

Samson, RA, Houbraken, J, Thrane, JC, Frisvad \& Andersen, F, 2010, Taxonomic studies on the genus Aspergillus, Fungal Biodiversity Centre Utrech, Netherlands.

Samson, RA, Houbraken J, Thrane, JC, Frisvad \& Andersen, F, 2011, Studies In Mycology : Identification and Nomenclature Of The Genus Penicillium, Fungal Biodiversity Centre Utrech, Netherlands.

Sarah ,K, Catriona, H, Helen ,A, \& David, E, 2016,' Descriptions of Medical Fungi, National Mycology Reference Centre Sa Pathology, Adelaide, South Australia.

Semangun H, 2000, Penyakit-Penyakit Tanaman Perkebunan di Indonesia, Ed ke-4, Yogyakarta: Gadjah Mada University Press.

Sennang, NR, Syam'un, E, \& Dachlan, A, 2012, 'Pertumbuhan dan Produksi Padi yang Diaplikasi Pupuk Organik dan Pupuk Hayati', Agrivigor, vol. 11, no. 2, hal. 161- 170.

Thongklang, N, 2010, Culture Condition, Inoculum Production and Host Response of a Wild Mushroom Phlebopus portentosus Strain CMUHH121-005, Maejo International Journal of Science and Technology, vol. 5 no. 3). hal: 413-425.

Tistama, R, \& Nugroho P, A, 2007, 'Mikrobia potensial untuk perkebunan karet', Warta Perkaretan, vol.1, no. 26 , hal. $40-51$.

Wulandari, E, 2012, Limbah Molas: Pemanfaatan sebagai Sumber Karbohidrat untuk Perkembangbiakan Mikroorganisme. ISSN, vol. 2 no. 5 hal: $565-572$. 